\title{
82. On the Relation between the Lower Ordovician Trilobites and Conodont Horizons in South Korea
}

\author{
By Teiichi Kobayashi, M. J. A. \\ (Communicated June 8, 1976)
}

In South Korea conodonts were first discovered by Müller in 1964 in the Older Palaeozoic rocks. Subsequently Lee (1970) stated that "the Dumugol (i.e. Tomkol) formation contains a mixture of European and subordinate American elements of Arenigian age." Recently he reiterated this age-determination, in describing 20 formspecies in 7 genera of the Diastaconodontidae from 4 horizons in the Dongjeom section, Samckeokgun, Kangweon-do. He collected sample 6 and samples 16, 17 and 19 respectively from the very basal part and the 25 meters' top part of the Dumugol shale and limestone alternating beds, about $180 \mathrm{~m}$ thick. A long barren intervening part of 150 meters' thickness tells a considerable time-gap. Really Drepanodus arcuatus is a sole common element between them. Fourteen short-ranged species particularly noted by Lee are tabulated below.

Thus the selected species are all Tremadocian-Arenigian except for an upper Tremadocian one and three Arenigian ones from the

\begin{tabular}{l|c|c|c|c}
\hline \hline Conodont species Horizon, sample & 6 & 16 & 17 & 19 \\
\cline { 1 - 2 } Acodus deltatus Lindström & uT-A & & & \\
A. oneontensis Furnish & & & T-A & \\
A. tetrahedron Lindström & uT-A & & & \\
Acontiodus rectus Lindström & T-A & & & \\
A. iowensis Furnish & & & T-A & \\
Distacodus stolus Lindström & T-A & & T-A & \\
Drepanodus arcuatus Pander & & & uT & \\
D. bisymmetricus Viira & & & T-A & T-A \\
D. homocurvatus Lindström & & & T-A & \\
D. parallelus Branson \& Mehl & & & T-A & T-A \\
Oistodus inaequalis Pander & & & T-A & \\
Paltodus inconstans Lindström & & & A & \\
P. variabilis Furnish & & & & A \\
Scolopodus rex Lindström & 4 & 0 & 10 & 3 \\
\hline Short-ranged species & 5 & 2 & 15 & 3 \\
Total species & & & \\
\hline
\end{tabular}

T: Tremadocian, A: Arenigian, u: upper 
top part. Therefore approximate ages of the samples 6, 17 and 19 are judged to be upper Tremadocian, basal Arenigian (or Trem.Arenig. transition) and lower Arenigian. Although Prioniodus or any other compound form was included in the Dongjeom conodonts, their alliance to those of the Latorpian stage, Ninemile formation and D zone of North America may be acceptable for the top assemblages. This means, however, that the sample 6 is much older.

Because no mention is given of the stratigraphic relation of the conodont horizons to the megafossil beds, an attempt is made in order to see how nicely do these horizons fit in the megafossil zonation. As detailed already (1966), the part of the Cambro-Ordovician Chosen group consists of three Ordovician formations and four fossil zones are in descending order as follows:

3. Chiktong limestone, 200 to $400 \mathrm{~m}$ thick, with Clarkella zone in basal part.

2. Dumugol shale beds, $150-200 \mathrm{~m}$ thick. $\left\{\begin{array}{l}\text { Protopliomerops zone } \\ \text { Asaphellus zone }\end{array}\right.$

1. Dongjeom quartzite, $5-50 \mathrm{~m}$ thick, yielding Pseudokainella in the northern wing of the Baegunsan syncline.

0. Hwajeol formation about $200 \mathrm{~m}$ thick, with Eoorthis zone in top part.

It is now thoroughly established that the Fengshanian-Peyntonian trilobite faunas containing Tsinania, saukids, etc. on the western Pacific province to which the upper Hwajeol formation belongs, is late Upper Cambrian and pene-contemporaneous with the Trempealeauan on the eastern Pacific side. The Tremadocian age of the Datsonian and Warenian stages superjacent to the Penytonian in Australia is warranted by conodonts ( $\mathrm{Lu}$, Chang et al. 1964, Kobayashi, 1967, 71, 76, Shergold, 1971, 75). Upper Cambrian age of the Hwajeol formation is also confirmed by conodonts (Lee, 1975).

\begin{tabular}{l|c|c|c|c}
\hline \multicolumn{1}{c|}{ Fossil zone } & Pseudokainella & Asaphellus & Protopliomerops & Clarkella \\
\hline Pseudokainella & $\times$ & & & \\
Kainella & & $\times$ & & \\
Asaphellus & $\times$ & & \\
Asaphopsis & $\times$ & & \\
Birmanites & & & \\
Protopliomerops & & & $\times$ & \\
Dikelokephalina & & & & \\
Hystricurus & & & & \\
\hline
\end{tabular}

Important trilobites as age-determiners in the above Lower Ordovician formations are shown above. Kainella is a Tremadocian genus. In Argentina two species of the genus occur in lower Tremadocian and one and two species of Pseudokainella respectively in the lower and upper Tremadocian beds. Asaphellus is a typical upper 
Tremadoc asaphid in England and Wales, but it occurs in Argentina both in the lower and upper Tremadocian. Therefore, assuming the Pseudokainella horizon to be early Tremadocian, the Asaphellus zone must be middle or upper Tremadocian. Apatokephalus appeared already in the early Tremadocian in Argentina and it became wide spread in North and Central Europe in the late Tremadocian age. Its lower Arenigian occurrence in South France is exceptional. Because Dikelokephalina occurs in the Apatokephalus zone in Sweden, their association reveals the late Tremadocian age of the Protopliomerops zone. In western North America the three Protopliomerops zones $\left(\mathrm{F}, \mathrm{G}_{1-2}\right)$ are in the middle part of the Canadian series. Finally, Dikelokephalina probably survived in Korea until the early Arenigian in view of its inclusion in the Clarkella zone with middle Canadian Hystricurus. Judging from these trilobites the Clarkella zone in Korea should be early Arenigian.

In Central China lower Tremadocian Hysterolenus yuhangensis $\mathrm{Lu}$ occurs below the Asaphellus-Birmanites zone in Chekiang. Asaphopsis as well as Birmanites inclusive of Birmanitella are wideranged, but Asaphopsis immanis and Asaphellus inflatus designate two Tremadocian zones, lying the former above the latter in Hupeh (Lu, 1975).

Thus it is warranted at present by regional and global correlations that these Tomkolian trilobites are exclusively Tremadocian. At the same time it is endorsed by the conclusion that the Tsinaniabearing Fengshanian-Peyntonian fauna is pre-Tremadocian, instead of Tremadocian (Whittington \& Hughes, 1974). Here the relative conodont horizons to the trilobite zones are tentatively tabulated as below.

\begin{tabular}{l|l|l}
\hline \multicolumn{1}{c|}{ Age } & \multicolumn{1}{|c|}{ Trilobites } & \multicolumn{2}{|c}{ Conodonts } \\
\hline Arenigian & Clarkella zone & Sample 19 \\
& & Sample 17 \\
& Sample 16 & Sample 6 \\
Tremadocian & $\begin{array}{l}\text { Protopliomerops zone } \\
\text { Asaphellus zone }\end{array}$ & \\
\hline \multirow{3}{*}{ Fengshanian } & Pseudokainella horizon & \\
\hline
\end{tabular}

When so arranged, there is no contradiction against conodont chronology, although the time-relation should be vindicated in the Dongjeom section by their actual field relation. With regard to the conodont frequency it can hardly be overlooked that the basal cono- 
dont assemblage is indicated by only 12 specimens in 4 species, but 139 specimens in 16 species from three horizons in the top part of 25 meters within which, remarkable enough, 122 specimens in 15 species were obtained from the middle horizon, i.e. sample 17. This means that the most conodont-rich horizon is within the Tremadocian-Arenigian passage beds. Is it why an Arenigian age emerged already in the preliminary survey? It is not the less noteworthy that Scolopodus rex with which Lee (1970) emphasized an Arenigian age of the Dumugol formation is known only from the horizon immediately beneath his Dumugol-Chiktong (his Maggol) boundary. There, however, it is so profused as 6 out of 10 specimens belong to this species. Because the boundary is, lithologically speaking, not so sharp as the base of the Dongjeom quartzite, the boundary is a question. Which is relevant to draw it below or above the rex-horizon? Leaving the top part for a future solution, now it can be said that not only megafossils but conodonts also proved the Tremadocian age of the Tomkolian series in the Dongjeom section.

\section{References}

Kobayashi, T. (1966) : The Chosen Group of South Korea. Jour. Fac. Sci. Univ. Tokyo, sec. 2, 16, pt. 1, 1-84.

- (1969): The Ordovician of Eastern Asia and other parts of the continent. Ibid., 17, pt. 2, 163-316.

- (1971): The Cambro-Ordovician provinces and the interprovincial correlation. Ibid., 18, no. 1, 129-299.

- (1976): Distribution of Cambrian trilobites in the Peri-Gondwana seas. Proc. Japan Acad., 52, 187-190.

Lee, Ha-Young (1970) : Conodonten aus des Chosen-Grüppe (Unteres Ordovizium) von Korea. N. Jb. Geol. Pal. Abh., 136, 303-44.

- (1975): Conodonts from the Dumugol formation (Lower Ordovician), South Korea. Jour. Geol. Soc. Korea, 11, no. 2, 75-93.

- (1975): Conodonts from the Upper Cambrian formations, Kangweon-do, South Korea and its stratigraphic significance. Yonsei Nonchong, 12, 71-89.

$\mathrm{Lu}$ Yen-hao (1975): Ordovician trilobites faunas of central and southwestern China. Palaeont. Sinica, N. S. B., no. 11, 463 pp. 50 pls.

Müller, A. K. (1932): Conodonten aus dem unteren Ordovizium von Südkorea. N. JB. Geol. Pal. Abh., 119, 93-102.

Shergold, J. H. (1971) : Resume of data on the base of the Ordovician in northern and central Australia. Colloque ordovicien-silurien. Brest, 1971. Mém. B. R. G. M. no. 73 , 391-402.

Whittington, H. B., and Hughes, G. P. (1974) : Geography and faunal provinces in the Tremadoc epoch. G. A. Ross (ed.) Paleogeographic provinces and provinciality. Soc. Econ. Pal. \& Min. Sp. Publ. no. 21, 203-18.

See Kobayashi, 1969, 71 for other references 